\title{
The Problems that Encounter Palestinian Olive Oil Marketing
}

\author{
Mansoor Maitah $^{1}$, Khaled Zidan ${ }^{1} \&$ Karel Malec $^{1}$ \\ ${ }^{1}$ Department of Economics, Faculty of Economics and Management, Czech University of Life Sciences Prague, \\ Czech Republic \\ Correspondence: Mansoor Maitah, Faculty of Economics and Management, Czech University of Life Sciences \\ Prague, Kamycka 129, Prague 6, 16921, Czech Rep. E-mail: Maitah@pef.czu.cz
}

Received: September 14, 2014

Accepted: October 14, $2014 \quad$ Online Published: November 23, 2014

doi:10.5539/mas.v9n1p58

URL: http://dx.doi.org/10.5539/mas.v9n1p58

\begin{abstract}
This study aimed to identify the problems and barriers encounter Palestinian olive oil marketing and the possible solutions to promote marketing. The instrument for data collection was via well structured and protested questionnaires. The Sample of the study consisted of 30 Palestinian farmers which were randomly chosen. The data collected through the field survey has been analyzed using descriptive statistical method. The results of the statistical analysis revealed that the high cost increases the problem of marketing the olive oil; the Israeli procedures affect the marketing of the olive oil in the Palestinian territories, the low expenditure on advertising increases the problem of marketing and there is no planning for marketing the Palestinian olive oil. Several recommendations have been suggested by this research.
\end{abstract}

Keywords: palestinian olive oil, promoting marketing, agriculture

\section{Introduction}

Because of the suitable climate and fertile soil, Palestine is considered one of the olive oil producers. On the other hand, some obstacles due to the situations of the Palestinian territories hinder these amounts of production, particularly, marketing procedures and its distribution. (Palestinian Central Bureau of Statistics, 2008). This problem is one of the worst disasters affecting the farmer who is severely influenced by the loose of his products and the spoilage of his harvest. Olive tree is one of the Palestinian national economy pillars as Palestine has more than 262 thousands donoms (1000sq meters) of planted land with it according to the statistics of the Palestinian Agriculture Ministry and UN Development Program.

Olive oil contributes more than $25 \%$ of the Palestinian national economy. So, several specialists in agriculture have warned against a real crisis in regard to exporting the extra oil quantities which overflow the local needs for consumption in the few years. These quantities will reach 100 thousand tons of olive oil in 2013 (Palestinian Agriculture Ministry, 2007).

Marketing olive oil is an enormous obsession in Palestine for several reasons included the lack of clear plan or strategy for marketing adopted by the Government and the absence of an international marketing strategy dealing with these agricultural products. So, it is necessary to carry out a study about the problems of marketing olive oil in Palestine in order to conclude some suggestions and ideas based on the other developed countries experiments in this respect.

Hence, this study has been prepared whereby the researchers seek to achieve the following objectives:

- Clarifying the problems encounter the Palestinian olive oil marketing and how to enter the international market by developing strategies.

- The problems of marketing the Palestinian olive oil and how can we enhance its marketing.

- The procedures of approaching the international markets for marketing the Palestinian olive oil.

- The effects of the Israeli procedures against the marketing of the olive oil.

- The roles of the variables of the (monthly income, years of experience, place of residence, amount of the harvest and academic qualification) on the farmers' responses towards the subject of marketing the olive oil promoting the procedures of export.

- Results and recommendations which reinforce farmers, researchers and workers for the Ministry of 
Agriculture.

\section{Literature Review}

\subsection{The Concept of the International Marketing}

International marketing is an exchange operation happening across the national boarders in order to meet the society needs and desires. So, this exchange creates slot of obstacles with special natures. Unsure factors in the international scope cause several uncontrolled variables inside the international markets like tax differences, political and economical systems, in addition to the legal and legislative framework, and the cultural differences between people. Accordingly, several unsure factors surrounding the international market environment indicate the importance of paying attention to some various marketing procedures (external marketing studies, and improving the marketing mixture in order to suit the demands of the international agent).The more increasing of the mentioned importance, the more complicated variables (Sak Onkvisit, John J. Shaw, 2004).

The international marketing agent must gain some sensitivity for the various marketing environment in order to acquire the ability to practice several marketing efforts at the international marketing level. This concept needs achieving the following:

- Designing the international marketing mixture for the international markets.

- Coordinating the marketing activities in order to enter the international level.

- Achieving the integration between the marketing activities and the others in the organization.

In fact, the marketing environment differs enormously between countries either they have the same geographical region or the same cultural roots. The following illustration explains the above idea:

\begin{tabular}{|c|c|c|c|}
\hline Technical factors & International agreements & International organizations & $\begin{array}{l}\text { International } \\
\text { competition }\end{array}$ \\
\hline
\end{tabular}

The products

Pricing

International agent

Distribution

Promotion

Cultural factors Economical factors Political factors Legal factors

Source: International marketing environment (Sak Onkvisit, John J. Shaw, 2004. P18).

\subsection{Reasons for Practicing the International Business}

The term "International Business" refers to the business activities across borders. Some factors which expected to grow largely in few years later result these activities like the desire for a few growths that the organizations plan to, referred to various factors influenced the practicing of the international marketing activities which have several images as the following (Subhash C. Jain, 2001):

\section{Globalization}

The international organizations should take advantages from the advanced telecommunication and informational technology that has completed the World to be a small village and the needs of the individuals from deferent cultures became closely related. The advantages included planning marketing procedures in order to insure its competitive abilities, and producing unified marketed international products at the same level of the international demands (Subhash C. J., 2001).

\section{The local competition}

In most cases, few organizations may think - as a result of competition pressures in its local markets - about abroad markets which have no strong competition in order to distribute the products (Subhash C. J., 2001).

\section{Expanding the Life Circle of the Product}

Exporting the product would increase the expanding the growth stage for life circle of the product .For example, small refrigerators are preferred to be exported to some countries which use them as a secondary products not basic ones like using them in the studios and students' rooms etc.

\section{Foreign Subsidiaries Programs}


The foreign subsidiaries programs help the developing countries in establishing new markets for the industrial countries. The programs will facilitate purchasing products and services from the donations, except when these products are available in the country.

\section{The appearance of New Markets}

The new trends towards the free markets in most countries in the West and the East resulted new markets for growth and spreading out of the international organizations. This phenomenon has occurred in Eastern Europe and the Middle East as a model.

\section{Gaining Tax Advantages}

Some organizations prefer to approach the international markets in order to gain some custom and tax advantages (For example: free tax policy).

\section{Local Market Satisfaction}

In most cases, the local markets reached the point of satisfaction for some products. So, it is must to look for new markets. The best alternative of the first stages markets will be the international one which is characterized by attractiveness. For example, the T.V and car markets in some countries like America which has population growth less than the expected for selling these products. (Subhash C. J., 2001).

\subsection{Techniques and Procedures for Approaching the International Markets}

The common techniques used in our Arabic environment for targeting the international markets are:

\section{Export}

The organizations resort to the export policies in order to limit the risk factors of the international dealing. Numerous advantages of export are available such the low cost of the export when compared with other alternatives. Moreover, the easiest alternative to deal with the international markets in addition to be a good tool for achieving the international experience (Dommor \& Zamel, 2006).

\section{Contractual Agreements}

These agreements are long- term connections between international organizations and local one in another country in order to transfer advanced technology and knowledge rights from one party to another without investments in concrete assists from the first party. The contractual agreements have several forms such manufacturing, authorization, delivery and administrative contracts.

\section{Direct Investment}

The highest level of risk factors is demonstrated by this procedure when entering the international markets. The international firm invests directly in productive projects which are entirely owned by the international firm itself in the targeted market. This kind of investment has its own advantages and drawbacks:

\begin{tabular}{ll}
\hline Advantages & Drawbacks \\
\hline $\begin{array}{l}\text { The entire exploitation of the competitive quality } \\
\text { of the international firm. }\end{array}$ & $\begin{array}{l}\text { The need for huge capitals and administrative } \\
\text { resources accompanied by risk factors. }\end{array}$ \\
$-\quad \begin{array}{l}\text { Reducing the cost of supplying the } \\
\text { product. }\end{array}$ & $\begin{array}{l}\text { - Incorrect interpretation of data could result the } \\
\text { fail in some investments. }\end{array}$ \\
- Creating some various marketing & - The high cost of establishing the investment \\
qualities for the international firm as & long period of payback and the inability to \\
a result of its close location to the & withdraw in case of fail \\
local market and the final customer & \\
\hline
\end{tabular}

Source: Hollensen S., 2007. P.6.

\section{Mutual Projects}

Both, the direct investment and mutual projects have the same grade of high risks .On the other hand, the later is cooperation in the property with a particular ratio between local and foreign companies in a targeted market in order to achieve some profits. This technique has advantages and drawbacks: 


\begin{tabular}{cll}
\hline Advantages & & Drawbacks \\
\hline$-\quad$ Achieving higher revenues and & - There is a high level of risk. \\
controlling the process of & - Huge investments in capitals and human \\
production and marketing. & recourses are needed. \\
$-\quad \begin{array}{l}\text { Providing feedback about the } \\
\text { targeted market and acquiring }\end{array}$ & $\begin{array}{l}\text { between the project and the total operation of the } \\
\text { experience in the international }\end{array}$ & international company. \\
markets. & \\
Confiscation and & \\
nationalization is low rates &
\end{tabular}

Source: Hollensen S, 2007. P.6.

\subsection{Over View of the Palestinian Olive Oil Sector}

Olive tree occupies a paramount importance in the economic and social life of the Palestinian people, this branch consists one of the most important resources of income in the agricultural sector which in some years contributes more than $12 \%$ of the agricultural production. The export of these products has reached the primacy for several years. Consequently, it has played an important role in the Palestinian commercial balance. Moreover, olive oil is one of the most vital substances for the Palestinians and it is considered an important element for food assurance. Olive products compose the major raw materials for numerous related industries such oil squeezing, olive pickling, wood manufacturing and Jeft manufacturing. It is very important to note that the olive trees cover $45-55 \%$ of the agricultural area in Palestine and this percentage constitutes about $80 \%$ of the planted land of fruitful trees. Also, the olive tree is the most one spread. According to the statistics of the Palestinian Ministry of Agriculture, the olive tree contributes with $10-25 \%$ of the Palestinian national income.

According to the mentioned above, any changes in this branch will influence the national level of social and economic life of the Palestinian in the future because this tree symbolizes the steadfastness of the people on their land and despite the devastating for the olive tree, the people replant more and more. In 2000, the planted land with olives in Palestine reached 880 thousand donoms (1000sq meters) depending on the rainfall, In Gaza Strip; 10 thousand donoms are planted with 10 thousands olive trees depending on irrigation. The production reaches (35) thousands of oil and this number decreased to (7) thousands in the years of bad production. In general, the production is (18) thousands tons and in the exceptional years in declines to be (500) tons. Part of these quantities is used as pickled fruits; the rest usually being squeezed for oil.

The six Northern Governorates of Palestine (Tulkarm, Selfeet, Nablus, Jenin, Qalqeeliah and Tubas) occupy the primacy in producing olives and there are 79300 donoms planted with olive trees in all areas. The following table illustrates the geographical distribution of the olive oil areas:

\begin{tabular}{ll}
\hline Governorate & Space ( Hectare ) \\
\hline Tulkarm & 18450 \\
Nablus & 16826 \\
Ramallah & 15100 \\
Jenin & 14950 \\
Beithlehem & 1470 \\
Hebron & 6320 \\
Qalqeliah & 4450 \\
\hline
\end{tabular}

The Palestinian National Authority has cared about the oil production so, it has published a new criteria with an international standards for the production of the olive oil included limiting the general chemical and physical needs of the olive oil.

Palestinian olive oil has been classified into three groups: the deluxe with acidity not more than $1 \%$, the high 
quality with acidity not more than 1.5 and the ordinary with an acidity of $3.3 \%$ and less. For the storage sake, some factors have to be taken into consideration: the oxidation factor shouldn't reach more than $20 \%$, and new cans for first utilize must be used. According to the Palestinian National Authority (PNA) new criteria, olive oil should be stored in suitable places far from humidity, light and pollution. In Palestine, bearing exchange phenomena is the most important factor which causes the abrupt vacillation in producing olive oil in Palestine due to the fact that the most of the trees are from old age. Also, it is important to know that 100 thousands families depend on the olive tree in their life.

The individual's need from olive oil in Palestine is about (9-10) years yearly. On the other hand, the population (3.303 Million) needs 15 thousand tons of olive oil yearly. Consequently, it is essential to notice the importance of the domestic market for overcoming the problem of marketing the olive oil.

The Ministry of Agriculture refers that there are two sessions for the production of the olive oil based on the trees:

1) High level of production.

2) Low level of production.

The first level of production reached (35) thousand tons of olive oil in 1993 and 2002, so it is correct to say that the consumed quantity and the price depends largely on the seasons. The importance for the "Rural Factory" for canning the products emerges to be a high need in order to fulfill the increased orders for the markets in the bad sessions (Palestinian Central Bureau of Statistics (2009).

The olive oil is characterized by biological characteristics because it has perfumes, distinctive substances and low rate fats. Upon the past Ages, the Mediterranean people used to consume the olive oil so the planting of the trees is still expanding despite the high costs especially the cost of picking up the harvest which is $50 \%$ out of the total cost in some countries.

In Palestine, there is an average of about 34000 tons yearly in the good session; On the other hand, the average declines to the amount of 1000-6000 tons in the bad season (Ministry of Agriculture publications, 2011)

The Palestinian farmer adjusts his life by using the stored product from the previous years. In fact, the Palestinian olive oil is considered one of the best in the World because its brand (Souri) has good taste and color. In order to keep its status in the national markets, it should be kept in its high quality situation. The problem of the olive oil overflow in the domestic markets has risen in the beginning of the $20^{\text {th }}$ century. In the past, the Palestinian oil could reach the Jordanian and other Arabic World markets easily, but in the past few years the Jordanian production of oil raised to meet the needs of the local markets so, the exported amount decreased from 6-8 thousand tons to reach 1000-1500 tons yearly (Nashouhi, 1947)

On the other side, the Israeli markets consume 1000-1500 tons of the Palestinian olive oil yearly; 500 tons for the Arabian Gulf countries and 500 tons for the American markets which have been opened just before few years. Most quantities are exported to the Arabic countries by traditional 16 litters can (Hollensen S, 2007).

In 2000/2001, the problem of overflow has raised greatly as a result of the abundance of the production and the consumer's weakness of purchasing. Also, the increasing offers have deepened the problem as a result of the need for income caused by the economic situation of Al-Intifada.Several reasons have increased the problem of the overflow of the Palestinian olive oil included the loss of the Jordanian markets, the traditional ways of storing and canning the products which decrease the ability to find the chance in the international markets and the inability to compete in the external markets as a result of the high cost.

Generally speaking, it is expected that the problem of extra amounts of the olive oil will disappear in 2013 because the production average will balance the consuming one. Also, it is expected that the consuming average will increase slightly.

Recently, ways of marketing differ from the past. The marketing becomes directly from the farmer himself to the consumer who prefers purchasing it directly without the help of the agents in order to avoid the cheating problem. Although the standard system placed by the authority, the olive oil is still without control when being marketed. On the other hand, the exported quantities are subjected to some tests of acidity, Biroxodic number and cheating. These tests are limited.

To conclude that the only problem encounters the Palestinian farmer is the problem marketing the olive oil. So, more efforts should be done for the procedure of marketing the Palestinian olive oil outside Palestine. The limited number of the companies, the adequate experience in the international markets, and the lack of studies about this problem and the absence of advertising procedures are not enough in this area. 


\section{Hypothesss}

In the light of study objectives, the hypothesis of the study can be drawn up as follows:

Ho 1: There is no relationship between the problems of marketing the Palestinian olive oil and enhancing the improvement of its marketing due to the variable of the farmer's academic qualification.

Ho 2: There is no relationship between the problems of marketing the Palestinian olive oil and enhancing the improvement of its marketing due to the variable of the farmer's years of experience.

H0 3: There is no relationship between the problems of marketing the Palestinian olive oil and enhancing the improvement of its marketing due to the variable of the farmer's monthly income.

Ho 4: There is no relationship between the problems of marketing the Palestinian olive oil and enhancing the improvement of its marketing due to the variable of the farmer's place of residence.

Ho 5: There is no relationship between the problems of marketing the Palestinian olive oil and enhancing the improvement of its marketing due to the variable of the amount of the harvest.

\section{Methodology and Research Design}

\subsection{Study Population and Sample}

The study population consists of all farmers in the area of Selfeet, Madama, Deer Al-Hattab, Nablus, Salem and Beet Iba. The Sample of the study: consisted of 30 farmers which were randomly chosen. The sample was distributed according to five independent variables. Tables 1, 2,3,4,5 show the distribution of the sample.

Table 1. Sample distribution according to monthly income variable

\begin{tabular}{lll}
\hline Monthly income & Frequency & Percentage \\
\hline Less than 300 USD\$ & 8 & 27.0 \\
300-600 USD\$ & 12 & 40.0 \\
More than 600USD\$ & 10 & 33.0 \\
Total & 30 & 100.0 \\
\hline
\end{tabular}

Table 2. Sample distribution according to Academic qualification variable

\begin{tabular}{lll}
\hline Academic qualification & Frequency & Percentage \\
\hline School & 12 & 40.0 \\
University & 18 & 60.0 \\
Total & 30 & 100.0 \\
\hline
\end{tabular}

Table 3. Sample distribution according to Years of experience variable

\begin{tabular}{lll}
\hline Years of experience & Frequency & Percentage \\
\hline Less than 2 years & 4 & 13.0 \\
2-5 years & 6 & 20.0 \\
More than 5 years & 20 & 67.0 \\
Total & 30 & 100.0 \\
\hline
\end{tabular}

Table 4. Sample distribution according to amount of the harvest variable

\begin{tabular}{lll}
\hline The Harvest & Frequency & Percentage \\
\hline Less than 1 ton & 9 & 30.0 \\
$1-3$ tons & 16 & 53.0 \\
More than 5 tons & 5 & 17.0 \\
Total & 30 & 100.0 \\
\hline
\end{tabular}


Table 5. Sample distribution according to place of residence variable

\begin{tabular}{lll}
\hline Monthly income & Frequency & Percentage \\
\hline City & 2 & 7 \\
Village & 25 & 83 \\
Refugee camp & 3 & 10 \\
Total & 30 & 100.0 \\
\hline
\end{tabular}

\subsection{Methods of Collecting Data}

References were made to numerous researches and studies published in the scientific periodicals and magazines related to the subject matter of this research. Besides, researchers designed a questionnaire for this study on the basis of the theoretical framework along with the former studies.

In order to test the degree of reliability underlying the questionnaire results and the coherence of the questions therein, these were submitted to a group of colleagues, university professors at the departments of agriculture along with some specialists in the subject to judge them and express their views on the sound drafting of the questionnaire and coherence of its paragraphs. Besides, the reliability analysis was also used to work out the Cronbach's Alpha Coefficient whose value turned out to be around $79.3 \%$. As this value exceeds the acceptable ratio amounting to $60 \%$ (Zikmund, et. al., 2010), this means that the questionnaire results are reliable and their reliability can be trusted towards realizing the objectives of this study.

\section{Data Analysis and Testing the Hypothesis}

For testing the hypothesis, the "T-test" was used for one sample, and one way anova.

Testing of First Hypothesis

Ho1: "There is no relationship between the problems of marketing the Palestinian olive oil and enhancing the improvement of its marketing due to the variable of the farmer's academic qualification".

For testing the hypothesis, the "T-test" was used for one sample. Table No. (6) shows the results of testing the first hypothesis:

Table 6. Results of testing the first hypothesis according to the (T- test) for one sample

\begin{tabular}{|c|c|c|c|c|c|c|}
\hline & & & & df & $\mathrm{T}$ & Sig. \\
\hline $\begin{array}{l}\text { School } \\
(n=12)\end{array}$ & & $\begin{array}{r}\text { Univers } \\
(\mathrm{n}=18)\end{array}$ & & & & \\
\hline means & s. deviation & means & s. deviation & 28 & & \\
\hline 2.756 & 0.4707 & 4.828 & 0.358 & & 0.194 & $0.019^{*}$ \\
\hline
\end{tabular}

Table 6 shows that the mean of answers to the question which measure the relationship between the problems of marketing the Palestinian olive oil and enhancing the improvement of its marketing due to the variable of the farmer's academic qualification is studied (i.e. 4.828) is larger than the presumed mean (i.e. 3), and the (T) value has reached the statistical significance level at a reliability level of $95 \%(\alpha=0.05)$ and less. Therefore, the null hypothesis is rejected and the alternative hypothesis is accepted. In other words, there is significant relationship between the problems of marketing the Palestinian olive oil and enhancing the improvement of its marketing due to the variable of the farmer's academic qualification.

\section{Testing the Second Hypothesis}

Ho2: "There is no relationship between the problems of marketing the Palestinian olive oil and enhancing the improvement of its marketing due to the variable of the farmer's years of experience". The (One Way Anova) results on the differences in the degree of the problems of marketing the Palestinian olive oil and enhancing the improvement of its marketing from the farmers' Perspectives due to amount of the harvest. 
Table 7. The results of testing the second hypothesis

\begin{tabular}{llllll}
\hline Amount of the harvest & Sum of squares & D f & $\begin{array}{l}\text { Mean } \\
\text { square }\end{array}$ & F & Sig. \\
\hline Between groups & 0.769 & 2 & 0.384 & 0.909 & 0.016 \\
Within groups & 11.072 & 27 & 0.201 & & \\
Total & 11.841 & 29 & & & \\
\hline
\end{tabular}

These result showed that there were significant differences at $\{\alpha=0.05\}$ in the degree of the problems of marketing the Palestinian olive oil and enhancing the improvement of its marketing from the farmers' Perspectives due to the amount of the harvest.

\section{Testing the Third Hypothesis}

Ho3: "There is no relationship between the problems of marketing the Palestinian olive oil and enhancing the improvement of its marketing due to the variable of the farmer's monthly income". The (One Way Anova) results on the differences in the degree of the problems of marketing the Palestinian olive oil and enhancing the improvement of its marketing from the farmers' Perspectives due to Years of experience

Table 8. The results of testing the third hypothesis

\begin{tabular}{|c|c|c|c|c|c|}
\hline $\begin{array}{l}\text { Years } \\
\text { experience }\end{array}$ & Sum of squares & $\mathrm{Df}$ & $\begin{array}{l}\text { Mean } \\
\text { square }\end{array}$ & $\mathrm{F}$ & Sig. \\
\hline Between groups & 0.769 & 2 & 0.384 & 1.409 & 0.175 \\
\hline Within groups & 11.072 & 27 & 0.201 & & \\
\hline Total & 11.841 & 29 & & & \\
\hline
\end{tabular}

These result showed that there were no significant differences at $\{\alpha=0.05\}$ in the degree of the problems of marketing the Palestinian olive oil and enhancing the improvement of its marketing from the farmers' Perspectives due to the Years of experience.

\section{Testing the Fourth Hypothesis}

Ho4: "There is no relationship between the problems of marketing the Palestinian olive oil and enhancing the improvement of its marketing due to the variable of the farmer's place of residence". The (One Way Anova) results on the differences in the degree of the problems of marketing the Palestinian olive oil and enhancing the improvement of its marketing from the farmers' Perspectives due to the place of residence.

Table 9. The results of testing the fourth hypothesis

\begin{tabular}{llllll}
\hline Place of residence & Sum of squares & D f & $\begin{array}{l}\text { Mean } \\
\text { square }\end{array}$ & F & Sig. \\
\hline Between groups & $847 j 1$ & 2 & 0.616 & 3.327 & 0.022 \\
\hline
\end{tabular}

These result showed that there were significant differences at $\{\alpha=0.05\}$ in the degree of the problems of marketing the Palestinian olive oil and enhancing the improvement of its marketing from the farmers' Perspectives due to the place of residence.

\section{Testing the Fifth Hypothesis}

H05: "There is no relationship between the problems of marketing the Palestinian olive oil and enhancing the improvement of its marketing due to the variable of the amount of the harvest". The (One Way Anova ) results on the differences in the degree of the problems of marketing the Palestinian olive oil and enhancing the improvement of its marketing from the farmers' Perspectives due to the monthly income 
Table 10. The results of testing the fourth hypothesis

\begin{tabular}{llllll}
\hline Monthly income & Sum of squares & D f & $\begin{array}{l}\text { Mean } \\
\text { square }\end{array}$ & F & Sig. \\
\hline Between groups & 0.766 & 2 & 0.384 & 0.95 & 0.284 \\
Within groups & 11.071 & 27 & 0.201 & & \\
Total & 11.847 & 29 & & & \\
\hline
\end{tabular}

These result showed that there were no significant differences at $\{\alpha=0.05\}$ in the degree of the problems of marketing the Palestinian olive oil and enhancing the improvement of its marketing from the farmers' Perspectives due to the monthly income.

\section{Conclusion and Recommendation}

According to the previous statistical analysis, several results have been founded included the following:

- The farmer suffers from the problem that the product can't reach all the Palestinian territories.

- The security problems affect negatively on marketing olive oil.

- $\quad$ The high cost increases the problem of marketing the olive oil.

- The Israeli procedures affect the marketing of the olive oil in the Palestinian territories.

- The instability of the yearly production increases the problem of marketing.

- Civil society institutions support the farmers in marketing olive oil.

- The low expenditure on advertising increases the problem of marketing.

- The lack of marketing studies increases the obstacles of marketing the olive oil.

- The low experience which the farmer possesses increases the problem of marketing.

- There is no planning for marketing the Palestinian olive oil.

- The olive oil is being marketed directly from the farmer to the consumer.

- Marketing the Palestinian olive oil faces a few problems.

- Oil in the good seasons is not canned in order to meet the needs during the bad sessions.

- The Ministry of Agriculture doesn't cooperate with the farmers in marketing the olive oil

\section{Recommendations}

According to study results, several recommendations have been suggested such as the following:

1) The product must reach all the Palestinian territories.

2) Customs and taxes should be decreased because the high cost increases the problem of marketing the olive oil

3) Civil society institutions must support the farmers in marketing olive oil.

4) It is necessary to a wear the farmers about the the strategies of marketing in the international markets.

5) It is necessary to increase the expenditure on advertising in order to decreases the problems of marketing.

6) Several studies should be conducted about marketing the olive oil.

7) Planning for marketing the Palestinian olive oil must be existed.

8) It is necessary to adjust the agreements which prohibit the marketing of the olive oil regionally with the Israeli state.

9) Oil in the good sessions must be canned in order to meet the needs during the bad sessions.

10) The Ministry of Agriculture must cooperate with the farmers in marketing the olive oil.

\section{References}

Hollensen S. (2007). Global Marketing, Financial Times Prentice Hall (3th ed). p. 753. ISBN 978-0-273-70678-6.

Nashouhi, B. T. (1947). Olive growing in Palestine. Amman, Jordan. 
Onkvisit S., \& Shaw J. J. (2004). International Marketing: Analysis and Strategy (4th ed.), p. 594. Routledge. ISBN: 9780415311335.

Palestinian Ministry of Agriculture. (2007). The quantities of Olive oil production in Palestine. Annual Report.

Palestinian Ministry of Agriculture. (2008). The quantities of Olive oil production in Palestine. Annual Report.

Palestinian National Authority, Palestinian Central Bureau of Statistics. (2012). Olive Presses Survey 2011: Main Results. Ramallah - Palestine, 2012. Retrieved from http://www.pcbs.gov.ps/default.aspx

Subhash C. J. (2012). International Marketing Management (p. 570). Thomson South-Western. ISBN: 0324100868

Zikmund, W. G., Babin, B. J., Carr, J. C., \& Griffin, M. (2010). Business Research Methods (8th ed.), South-Western Cengage Learning, Mason OH, 647 p. ISBN: 9780324320626.

\section{Copyrights}

Copyright for this article is retained by the author(s), with first publication rights granted to the journal.

This is an open-access article distributed under the terms and conditions of the Creative Commons Attribution license (http://creativecommons.org/licenses/by/3.0/). 